\title{
Kebijakan Pemerintah Daerah tentang Pemakaian Bahasa Lokal: Studi Kasus Pemerintah Kota Surabaya pada Era Otoda
}

\author{
Tubiyono \\ Fakultas Ilmu Budaya Universitas Airlangga Surabaya
}

\begin{abstract}
Abstrak
Makalah singkat ini akan mendeskripsikan latar belakang, pelaksanaan, dan evaluasi tentang kebijakan pemakaian bahasa Jawa sebagai manifestasi good will pemerintah daerah Kota Surabaya pada era Otonomi daerah. Otonomi daerah memiliki implikasi yang sangat luas dalam kehidupan pemerintah daerah, tidak hanya beimplikasi pada masalah administrasi keuangan dan administrasi kepegawaian, tetapi juga masalah sosial, politik, ekonomi dan budaya. Salah satu implikasi yang berkaitan dengan masalah budaya adalah adanya kebijakan yang dikeluarkan oleh pemerintah Kota Surabaya terkait dengan penggunaaan bahasa Jawa sebagai salah satu bahasa lokal di Kota Surabaya di samping bahasa Indonesia, bahasa Madura, dan bahasa asing wajib digunakan satu hari dalam satu minggu baik dalam situasi resmi maupun tidak resmi di seluruh pendidikan dasar dan menengah. Adanya kebijakan itu mendapat respon yang berbeda-beda baik dari guru, murid, serta pejabat terkait. Kebijakan Pemerintah Kota Surabaya terkait dengan kebijakan yang dimaksud, jika memang positif diharapkan dapat dijadikan model proteksi bahasa lokal dalam rangka pemertahanan budaya di tengah-tengah kehidupan global.
\end{abstract}

Kata Kunci

Kebijakan merupakan keputus yang tidak memihak pada suatu pihak tertentu dalam rangka menciptakan situasi yang kondusif.

Bahasa Jawa merupakan bahasa yang dituturkan oleh sebagaian besar orang jawa sekaligus sebagai suatu hasil budaya suku Jawa.

Otoda merupakan singkatan dari Otonomi Daerah (otonomi yang memberikan hak dan wewenang kepada daerah untuk mengatur ruma tangganya sendiri sesuai dengan peraturan perundangundangan yang berlaku).

\section{Pengantar}

Dalam kedudukannya sebagai bahasa daerah, bahasa Jawa memiliki fungsi sebagai (1) lambang kebanggaan daerah, (2) lambang 
identitas daerah, dan (3) alat perhubungan di dalam keluarga dan masyarakat daerah (Halim, 1980). Bahasa Jawa memiliki hak hidup yang sama dengan bahasa Indonesia. Hal ini sesuai dengan penjelasan Undang-Undang Dasar 1945 yang mengamanatkan bahasa (daerah) Jawa akan dihormati dan dipelihara oleh negara termasuk pemerintah pusat atau pun daerah (Hasan Alwi dalam Riyadi, 1996). Dengan memperhatikan fungsi bahasa Jawa dan penjelasan Undang-Undang dasar 1945 tersebut dapat dipahami bahwa untuk pembinaan dan pengembangan bahasa Jawa memerlukan strategi yang tepat. Strategi yang tepat itu, bahasa Jawa dimaknai secara imperatif harus diproteksi baik secara mekanik maupun secara organik.

Proteksi bahasa Jawa secara mekanik - biasanya bersifat birokratik, teknik organisasi, dan teknik struktural - dapat diperhatikan dalam kasus di Kota Surabaya yaitu dengan kebijakan pemakaian bahasa Jawa satu hari penuh (fullday) di sekolah-sekolah baik tingkat dasar dan menengah; baik sekolah negeri maupun sekolah swasta. Hal ini merupakan manifestasi good will pemerintah Kota Surabaya pada era Otonomi daerah dalam rangka mengartikulasikan amanat UndangUndang Dasar 1945 melalui jalur pendidikan formal. Walaupun kebijakan Pemerintah Kota Surabaya tersebut masih sebatas imbauan (informal) belum diformalkan dalam bentuk perda (peraturan daerah) ternyata dapat menjadi stimulus yang cerdas. Karena dengan imbauan yang tidak lazim seolah-olah bertentangan dengan realitas yang dihadapi yaitu masalah sosial-ekonomi, politik, dan hukum, kemudian dikejutkan dengan penggunaan bahasa Jawa di lingkungan pendidikan dasar dan menengah sehingga mendapatkan respon dari media cetak dan elektronik. Sebagai ilustrasi proteksi bahasa Jawa secara mekanik lainnya adalah keputusan Gubernur Jawa Timur Nomor 188/188/KPTS/013/2005 
tentang kurikulum bahasa Jawa yang wajib dilaksanakan untuk jenjang SD dan SMP atau yang sederajat di seluruh wilayah Jawa Timur.

Proteksi bahasa Jawa secara organik adalah proteksi yang sangat memperhatikan ciri kultural sosiologis masyarakat Kota Surabaya. Surabaya yang secara mayoritas didominasi etnik Jawa di samping etnik lain seperti etnik Madura dan etnik lainnya. Dalam hal ini masyarakat (etnik) Jawa diberi ruang hidup untuk berkreasi dan beraksi untuk memberi makna sosialnya, memberi identitas sosialnya, dan memperkokoh sosialnya sehingga akan menjasi saka guru kebudayaan nasional. Hal yang ideal apabila secara organik masyarakat diberi kesempatan, diberi perhatian, dan kalau memungkinkan diberi fasilitas untuk memberi makna hidupnya. Aktivitas masyarakat Jawa pada umumnya muncul dari kesadaran dari dalam nuraninya yang kadangkadang kurang mendapat perhatian dari negara atau pemerintah. Masyarakat yang secara suka rela atau karena hobi berbahasa dan bersastra Jawa dengan membuat komunitas atau sanggar-sanggar yang dibiayai dari kantong anggotanya, bukan dari APBD (Anggaran Pendapatan dan Belanja Daerah) Kota Surabaya. Media cetak berbahasa Jawa yang terbit mingguan seperti Jaya Baya dan Penyebar Semangat yang terbit di Surabaya dibiayai oleh dirinya sendiri. Kegetiran seperti itulah yang membuat Nabonenar (2007) secara emosional menyatakan pemain ludruk, juru tembang macapat, pengarang, dan penyair Jawa, mati-matilah sendiri. Padahal secara faktual mereka -pegiat bahasa dan sastra Jawa- yang menyuburkan bahasa Jawa sehingga bahasa Jawa tidak menjadi inferior pada zamannya.

Uraian selanjutnya akan dikemukakan konsep otonomi daerah, dilanjutkan dengan deskripsi bahasa pada masa kini, deskripsi imbauan berbahasa Jawa, pelaksanaan, dan evaluasi imbauan pemakaian bahasa 
Jawa sebagai manifestasi good will pemerintah kota. Selain itu, juga akan dideskripsikan bagaimana sosok Bambang Dwi Hartono sebagai Wali Kota Surabaya pada era otonomi daerah.

Otonomi Daerah

Sejak disahkan Undanag-Undang Nomor 22 tahun 1999 tentang Pemerintahan Daerah dan Undang-Undang Nomor 25 tahun 1999 tentang perimbangan keuangan Pusat dan Daerah (direvisi tahun 2004) yang telah diimplementsikan sejak 2001, maka berbagai kewenangan serta pembiayaan dilaksanakan oleh birokrasi pemerintah daerah (Pemda). Saat itulah Pemda memiliki kewenangan yang besar untuk merencanakan, merumuskan, melaksanakan serta mengevaluasi kebijakan dan program pembangunan yang sesuai dengan kebutuhan masyarakat setempat.

Pemerintah daerah tidak lagi sekadar sebagai pelaksana operasional kebijakan-kebijakan yang telah ditetapkan oleh pemerntah pusat, tetapi pemerintah daerah diharapkan dapat menjadi agen penggerak dan agen perubahan pembangunan di daerah. Dengan otonomi daerah, hal apa pun yang dilakukan pemerintah daerah dapat dinilai oleh masyarakatnya. Kebijakan publik yang dipilih dan diimplemantassikan apakah mampu memberdayakan masyarakat menuju yang yang lebih baik?

Pada dasarnya otonomi daerah memberi kesempatan yang besar bagi pembangunan masyarakat di tingkat lokal dan membuka peluag baru bagi perbaikan kegiatan ekonomi dan kegiatan nonekonomi. Kenyataannya, makna otonomi daerah masih belum dipahami secara utuh oleh aparat birokrasi pemerintahan daerah (Agustino, 2007).

Pemerintah Kota Surabaya telah melaksanakan otonomi daerah dengan merumuskan berbagai kebijakan yang terkait dengan 
kepegawaian, keuangan, sosial, ekonomi, hukum, pendidikan, pertamanan, dan sebagainya. Walaupun dalam pelaksanaannya kadangkadang terkesan kontroversial karena belum dapat dipahami oleh masyarakatnya. Asumsi dan pemikiran wali kota belum dapat diselaraskan dengan cara berpikir rakyat yang diembannya, misalnya, imbauan pemakaian bahasa Jawa di sekolah-sekolah muncul berbagai respon yang berbeda (akan diuraikan pada bagian lain dalam tulisan ini).

\section{Pembahasan}

\subsection{Bahasa Jawa yang Menjadi Ibu Tiri di Jawa}

Kearifan budaya lokal yang dimilki Indonesia adalah salah satu hal yang paling membanggakan. Berbagai suku bangsa dan bahasa yang ada di Indonesia yang seharusnya terus dilestarikan, nampaknya saat ini telah mencapai titik nadhir - titik yang menggambarkan budaya lokal sudah tidak lagi diperhatikan bahkan ditinggalkan oleh para pewarisnya. Sungguh sangat ironis, tetapi itulah kenyataan yang dihadapi Indonesia saat ini, sudah mulai hilang identitas dirinya sebagai negara yang bersuku-suku dan berbudaya yang disatukan dengan istilah Bhineka Tunggal Ika. Saat ini, sudah mulai pelan-pelan tetapi pasti proses kematian atau kepunahan bahasa daerah (Kompas, 21 Mei 2008)

Melihat kondisi budaya lokal yang telah tergeser oleh westernisasi, nampaknya Pemerintah Kota dan Dinas Pendidikan Kota Surabaya tergugah dan berupaya mengembalikan lagi keeksotisan budaya lokal yang telah lambat laun tergerus zaman. Sejak 15 Januari 2008, Pemerintah Kota Surabaya dan Diknas sudah memberlakukan "wajib berbahasa Jawa di sekolah". Pemkot Surabaya mengambil kebijaksanaan ini bertujuan menyelamatkan bahasa Jawa dari kemunduran dan kepunahan yang semakin mendekat. Program ini diwajibkan di seluruh 
jajaran sekolah mulai dari tingkat dasar hingga menengah atas, baik swasta maupun negeri. Pemkot dan Diknas menekankan Bahasa Jawa yang harus dilestarikan di Surabaya. Hal ini dikarenakan komposisi penduduk yang mendiami Kota Surabaya mayoritas adalah suku Jawa (53\%) (www.surabaya.go.id)

Seperti halnya kebijakan baru pemerintah, pasti menuai kontroversi di berbagai kalangan. Memang, jika dilihat dari komposisi penduduk, 53\% suku Jawa, 25,5\% suku Tionghoa, 7,5\% suku Madura, $7 \%$ suku Arab, dan suku lain (sisanya), bukan hal yang mudah untuk mengimplementasikan kebijakan ini dengan baik. Seperti yang terjadi di salah satu SMP, terdapat seorang murid yang mengaku kesulitan menggunakan Bahasa Jawa di sekolah. Dia beralasan kedua orang tuanya bukan dari Jawa, ibu dari Medan dan bapak dari Batak. Selain itu, Kepala SMU CITA HATI Surabaya juga mengatakan bahwasanya kendala yang ditemui di lapangan adalah kebanyakan karena banyaknya murid yang berasal dari suku lain, Batak, dan kalaupun mereka bisa berbahasa Jawa, mereka lebih memilih memakai bahasa Suroboyoan. Namun belum adanya petunjuk terperinci dari Diknas juga menjadi salah satu kendala dari pelaksanaan kebijakan ini.

Melihat pentingnya pelestarian budaya lokal, khususnya Bahasa Jawa ini, Walikota Surabaya, Bambang DH, saat ditemui di kediamannya mengatakan bahwasannya telah dilakukan inspeksi mendadak di beberapa sekolah di Surabaya. Ini dilakukan untuk menunjukkan keseriusan Pemkot dan melihat respon masyarakat dalam menjaga kearifan budaya lokal yang telah menjadi ibu tiri di tanah kelahirannya. Bahasa Jawa yang seharusnya menjadi ibu kandung, sekarang malah bergeser menjadi ibu tiri yang ditakuti. Dan semoga dengan vitalisasi etnolinguistik ala Pemkot Surabaya ini mampu mendongkrak bahasa 
Jawa menjadi primadona di Jawa Timur, bukan bahasa Jawa mati di Jawa Timur.

\subsection{Imbauan Penggunaan Bahasa Jawa}

Kebijakan Pemerintah Kota Surabaya terhadap penggunaan bahasa Jawa (salah satu bahasa lokal) di lingkungan pendidikan dasar dan menengah, walaupun masih sebatas imbauan (informal) memiliki beberpa implikasi positif dalam masyarakat yang berkaitan dengan bahasa dan kelas sosial, etika atau kesopanan, khususnya dalam masyarakat Surabaya yang multietnik.

Pada dasarnya secara historis bahasa Jawa pernah digunakan dalam situasi formal atau kedinasan bahkan dapat dikatakan sebagai imperatif bagi kalangan para bupati (penguasa) Jawa pada zamannya (Oetomo, 1989). Dengan kata lain bahasa Jawa memiliki peran sangat tinggi dalam masyarakat. Seiring dengan perjalanan waktu datangnya kapitalis dari Eropa dengan bahasa asingnya hingga bahasa Melayu (Indonesia) membentuk kelas sosial baru yaitu kelas sosial menengah. Hal inilah yang dapat berpengaruh terhadap pergeseran (perubahan) perilaku berbahasa seseorang.

Pergeseran perilaku berbahasa Jawa ke bahasa Indonesia (bagi kelas menengah) secara logis dapat dimaknai adanya pergeseran orientasi nilai (value) bagi penuturnya. Penggunaan bahasa Jawa lebih menggambarkan orientasi nilai suasana yang mengarah pada nilai kesantunan atau nilai etika. Sebaliknya, penggunaan bahasa Indonesia lebih berorietasi pada nilai status penuturnya daripada nilai suasana kesantunan.

Oleh karena itu, ajakan Bambang Dwi Hartono sebagai Wali Kota Surabaya pada era otonomi daerah memiliki makna atau fungsional yang 
tinggi. Artinya Bambang Dwi Hartono mengajak masyarakatnya untuk kembali kepada kearifan lokal yang tersirat dalam pemakaian bahasa Jawa. Karena didasari oleh suatu pemahaman bahwa dengan berbahasa Jawa nilai-nilai seperti kesantunan, tata susila, tata krama, etika pergaulan akan berpengaruh pada perilaku masyarakatnya, khususnya anak didik. Dengan kata lain, imbauan itu sebagai respon atas keprihatinan sebagian anak didik sekarang yang mengarah kepada degradasi moral dan etika. Disadari atau tidak bahwa bahasa tidak hanya dibentuk dan ditentukan, tetapi bahasa juga dapat membentuk dan menentukan sejarah sosial dan sejarah kultural. Mestinya, bahasa bukan hanya sebagai instrumen pengungkap ide dan perasaan, melainkan juga harus mampu memenuhi kebutuhan komunikasi personal untuk mengkonstruksi pikiran dan perasaan suatu tatanan sosial dan kultural yang sebelumnya pernah ada atau bahkan belum ada sama sekali (Heryanto, 1989).

Nilai-nilai seperti kesantunan, tata susila, tata krama, dan etika pergaulan sehari-hari yang diimplementasikan dalam kehidupan nyata menunjukkan bahwa masyarakat itu telah tahu bahasa (tahu sopan santun) atau etnik Jawa mengatakan njawani. Oleh karena itu, Wali Kota Surbaya mengajak segenap warga kota untuk sadar dan menyadari betapa pentingnya nilai kesantunan yang terkandung dalam bahasa Jawa sebagai salah satu bahasa lokal di Surbaya di tengah-tengah situasi bahasa nasional, bahasa Indonesia, dan bahasa global, bahasa Inggris dan bahasa asiing lainnya. Warga Kota Surabaya harus maju tidak kalah dengan bangsa lain yang telah maju, tetapi jangan sampai lupa pada nilai-nilai kesantunan dan etika.

Imbauan Bambang Dwi Hartono, Wali Kota Surabaya yang memadukan bahasa Jawa, bahasa Indonesia, dan bahasa Inggris untuk 
sekolah berbasis internasional (SBI) merupakan pemecahan yang perlu mendapat apresiasi yang proporsional. Wawasan demikian sejalan dengan wawasan Driyarkara dalam Sudiarja (2007) yang menyatakan kebudayaan (bahasa) lokal merupakan muatan kuat yang harus ditanamkan dalam pendidikan kepribadian nasional. Sebagai iluustrasi yang dikemukakan Driyarkara adalah sangat prihatin jikalau tahu anakanak Jawa tidak njawani. Baginya kebudayaan lokal tidak bertentangan, tetapi awal dari pendidikan kepribadian nasional dan pendidikan global. Karenanya, setiap pendidikan budaya (bahasa) lokal (Jawa) pada akhirnya harus diintegrasikan dengan pendidikan nasional dan pendidikan global.

\subsection{Bambang Dwi Hartono dan Personal Characteristics-nya}

Ajakan kembali ke bahasa Jawa di Kota Surabaya identik dengan sosok Bambang Dwi Hartono yang posisinya sekarang sebagai Wali Kota Surabaya yang diusung oleh Partai Demokrasi Indonesia Perjuangan (PDIP) dan ajakan tersebut bergayut dengan Kepala Dinas Pendidikan Kota Surabaya, Sahudi, yang melaksanakan imbauan tersebut di lingkup kerjanya. Gerakan kembali ke bahasa Jawa melalui ranah pendidikan (walaupun satu hari di lingkungan sekolah) mengindikasikan kemauan kuat untuk kembali pada moral etik yang luhur yang dapat menjadi sumber nilai dan dapat dijadikan pedoman dalam berperilaku sehari-hari. Ibarat sabda pendita ratu tan kena wola wali karena sosok Bambang Dwi Hartono yang saat ini adalah sebagai leader pemerintahan Kota Surabaya sehingga segala tindakan (nonverbal) dan pernyataan (verbal) selalu berkorelasi dengan kekuasaan (politik). Apa pun yang dikatakan oleh penguasa bagaikan idu geni mengandung tuah apalagi pada era otonomi daerah. Keadaan yang demikian menggambarkan bahwa dalam realitas 
kehidupan sangat dipengaruhi oleh personal power yang terdapat pada diri Bambang D.H. Di samping personal power, ada karakter lain yang dapat dijadikan indikator suatu pernyataan memiliki pengaruh atau tidak yaitu personal characteristics (Chambers, 1995:3).

Dalam hubungannya dengan personal characteristics perlu diperhatikan dan diselidiki ungkapan-ungkapan yang berupa pernyataanpernyataan dan seruan-seruan secara verbal yang dapat dijadikan petunjuk untuk mengetahui bagaimana sosok Wali Kota Surabaya cara memikirkan, merasakan, dan mengartikulasikan dalam kekuasaan. Pendekatan secara verbalistik ini relatif jarang digunakan untuk menganalisis kekuasaan (politik).

Sesuai dengan motto Surabaya smart and care, maka Wali Kota Surabaya secara terus menerus mengartikulasikannya dengan berupaya membangun kemitraan seoptimal mungkin. Bambang Dwi Hartono tidak ingin hanya membangun wacana, tetapi realisasi atau bukti nyata yang hasilnya dapat dirasakan oleh segenap rakyat. Oleh karena itu, Bambang D.H. menjalin kerja sama dengan berbagai lembaga pemerintah dan swasta di Kota Surabaya dan sekitarnya, bahkan merambah ke daerah lain hingga kerja sama dengan lembaga yang berasal dari luar negeri.

Ilustrasi lain adalah ajakan atau seruan Bambang D.H. kepada pemain Persebaya untuk tidak melanjutkan kompetisi Liga Indonesia pada tahun 2005 silam yang berbuntut sanksi kepada dirinya tidak boleh menjadi orang nomor satu di Persebaya oleh PSSI. Selain itu, adanya wacana untuk merumahkan ratusan pegawai yang dinilai tidak produktif bukanlah gertak sambal yang bersifat verbalistik, tetapi betul-betul direalisasikan. Ada hal yang memotivasinya dan dapat menjadi salah satu obsesinya ialah bagaimana masyarakat Surabaya bisa maju seperti bangsa Jepang dengan tidak melupakan unsur kearifan lokal yang 
tersimpan dalam bahasa lokal mereka. Beberapa hal tersebut sebagai ilustrasi tentang personal characteristics yang melekat pada dirinya.

\subsection{Pelaksanan Imbauan Berbahasa Jawa di Sekolah-Sekolah}

Pelaksanan imbauan berbahasa Jawa di sekolah-sekolah dipercayakan kepada Kepala Dinas Pendidikan Kota Surabaya. Kepala Dinas Pendidikan Kota Surabaya ketika rapat dinas dengan para pengawas dan kepala sekolah mengemukakan imbauan Wali Kota Surabaya untuk menggunakan bahasa Jawa sehari penuh dalam satu minggu. Hal itu dibenarkan oleh salah satu pengawas yang ditemui di kantornya yaitu Jalan Jagir Wonokromo.

Untuk memantau bagaimana imbauan penggunaan bahasa Jawa di sekolah-sekolah, Wali Kota Surabaya memantau secara langsung di lapangan yaitu dengan mengadakan inspeksi mendadak (sidak). Saat ditemui di rumah Dinas Wali Kota Surabaya, dikemukakan bahwa tiap sekolah di wilayah kerjanya baik kepala sekolah, guru, dan murid supaya berbahasa Jawa. Berbahasa Jawa tidak hanya pada situasi santai (informal) di luar kelas, tetapi juga situasi formal di dalam kelas. Akibatnya, ketika mengajar matematika, biologi, kimia, sejarah, ekonomi dan mata pelajaran lain harus disampaikan dengan menggunakan bahasa Jawa banyak kesulitan yang dihadapi. Menurut penuturan Bambang D.H. ketika berbahasa Jawa, kepala sekolah, guru, dan murid tidak perlu takut salah menggunakan bahasa Jawa yang tidak sesuai dengan kaidah bahasa Jawa yang berkiblat ke barat yaitu Yogyakarta dan Surakarta.

Namun, Wali Kota Surabaya ini mengingatkan agar bahasa Jawa yang digunakan di sekolah-sekolah adalah bahasa Jawa yang tidak terkontaminasi eksplorasi salah satu stasiun televisi yang sarat dengan nilai seksualitas dan kekerasan. Oleh sebab itulah Bambang Dwi 
Mabasan - Vol. 2 No. 2 Juli-Desember 2008

Hartono tidak setuju dengan diksi-diksi pilihan stasiun televisi tersebut seperti: dilakeni, banyu londo, empal brewok, angin pentil muter, dan sebagainya.

\subsection{Respon Pemakaian Bahasa Jawa di Sekolah}

Respon pemakaian bahasa Jawa di sekolah-sekolah dasar dan menengah berbeda-beda. Berdasarkan penuturan sorang guru bahasa Inggris dari salah satu SMAN di Surabaya membenarkan adanya imbauan penggunaan bahasa Jawa pada setiap hari Senin. Akan tetapi, ada beberapa kendala yang ditemukan di lapangan. Kendala itu antara lain muncul dari faktor guru dan murid. Guru dan murid dalam suatu sekolah sangat beragam ada sebagian yang dapat menerima ada sebagian yang sukar menerima penggunaan bahasa Jawa.

Respon seorang guru bahasa Inggris pada salah satu SMAN di Surabaya menuturkan bahwa implementasi pengguanaan bahasa Jawa di sekolah-sekolah terdapat beberapa kendala yang dihadapi. Kendala itu antara lain kondisi siswa, guru, dan pegawai masing-masing sekolah sangat beragam etnik. Sedain itu, relatif minimnya kebiasaan penggunaan berbahasa Jawa dalam kehidupan sehari-hari ketika berinteraksi dengan orang-orang di sekitarnya.

Seorang murid kelas $\mathrm{X}$ di salah satu SMAN di Surabaya kebetulan ketika dijumpai menginformasikan bahwa di sekolahnya tidak ada guru yang menerangkan materi pelajaran yang menggunakan bahasa Jawa. Informasi ini menunjukkan bahwa ajakan Wali Kota Surabaya belum sepenuhnya dilaksanakan dengan secara menyeluruh untuk lingkungan sekolah. Namun demikian adanya ajakan Wali Kota untuk berbahasa Jawa ini mendapatkan respon positif dari berbagai masyarakat 
yang dapat dipantau dari internet bahkan tidak hanya dari lingkungan masyarakat Surabaya, tetapi dari daerah lain.

\section{Penutup}

Upaya yang dilakukan Wali Kota Surabaya merupakan langkah strategis untuk memproteksi bahasa Jawa (salah satu bahasa lokal) dan sekaligus menghambat proses kepunahan yang saat ini digelisahkan oleh Dendy Sugono, Kepala Pusat Bahasa Nasional. Karena saat ini sembilan bahasa daerah telah punah dan 65 bahasa daerah terancam punah dari 746 bahasa daerah yang ada di Indonesia (Kompas, 21 Mei 2008).

Untuk menghadapi masalah eksistensi bahasa daerah yang masih bertahan, Pusat Bahasa tengah mencari strategi guna mempertahankan bahasa-bahasa daerah tersebut. Oleh karena itu, ajakan Bambang Dwi Hatono, Wali Kota Surabaya, untuk menggunakan Bahasa Jawa sehari dalam satu minggu di lingkungan sekolah-sekolah dasar dan menengah di Surabaya merupakan salah satu alternatif solusi untuk memproteksi keberadaan bahasa Jawa supaya tidak cepat dilupakan dan akhirnya punah seperti sembilan bahasa daerah lainnya yang tinggal kenangan.

Imbauan untuk menggunakan bahasa daerah di sekolah-sekolah saat ini masih bersifat lisan (lebih informal) dan belum memiliki payung hukumnya sehingga menyulitkan pelaksanaan di lapangan. Masalah ini akan menjadi lain apabila diformalkan dalam bentuk peraturan daerah (perda) Kota Surabaya yang bersifat mekanik sehingga memiliki landasan atau pijakan yang jelas dan memiliki makna imperatif bagi lembaga yang relevan.

Upaya lain yang dilakukan Wali Kota Surabaya dalam rangka memproteksi bahasa Jawa dan bahasa daerah lain secara temporal difasilitasi dengan menciptakan ruang hidup bagi budaya Jawa dan 
Mabasan - Vol. 2 No. 2 Juli-Desember 2008

budaya lokal lainnya dalam bentuk festival seni dan budaya yang dikaitkan dengan hari jadi Kota Surabaya. Ke depan diharapkan adanya perhatian yang lebih dari wali Kota Surabaya kepada pegiat bahasa Jawa, sastra Jawa, dan media cetak yang menggunakan bahasa Jawa. 


\section{Daftar Pustaka}

Agustino, Leo. 2007. "Negara Pusat Negara Lokal” Basis. Nomor 01-02 Tahun ke-56.

Chamber, J.K. 1995. Sociolinguistic Theory Linguistic Variation and its Social

Significance. Cambridge, Massachusetts: Blackwell.

Halim, Amran (Ed.). 1980. Politik Bahasa Nasional 2. Jakarta: Balai Pustaka

Heryanto, Ariel. 1989. "Berjangkitnya Bahasa-Bangsa di Indonesia" Prisma. No.1. Tahun XVIII.

Keputusan Gubernur Jawa Timur Nomor 188/188/KPTS/013/2005 tentang Kurikulum Mata Pelajaran Bahasa Jawa untuk Jenjang Pendidkan SD/SDLB/MI dan SMP/SMPLB/MTs Negeri dan Swata Propinsi Jawa Timur.

Kompas. 2008. "Sembilan Bahasa Punah, 65 Bahasa Terancam" Kompas, 21 Mei 2008.

Nabonenar, Bonari.2007. "Perlukah Dewan Bahasa Jawa?" Kompas. Maret 2007.

Oetomo, Dede. 1989. "Bahasa Indonesia dan Kelas Menengah Indonesia” Prisma. No.1. Tahun XVIII.1989.

Riyadi, Slamet. 1996. "Kebijakan Pembinaan dan Pengembangan Bahasa dan Sastra Jawa dan Penerapannya di SLTP" dalam Widyaparwa. Balai Penelitian Bahasa Yogyakarta.

Sudiarja, A. 2007. "Driyarkara: Pendidikan Kepribadian Nasional" Basis. No. 07-08, Tahun ke-58, Juli-Agustus 2007.

www.surabaya.go.id 